\title{
An Industry Analysis of the Power of Human Capital for Corporate Performance: Evidence from South Africa
}

\author{
Carla Morris \\ School of Accountancy, Stellenbosch University \\ Accepted: May 2015
}

\begin{abstract}
Even in industrialised emerging economies, the value-generating competencies of a workforce, known as its human capital efficiency, are a key resource for commercial success. The objective of this research is to empirically investigate the relationship between human capital efficiency (as measured by value-added human capital) and the financial and market performance of companies listed on the Main Board and Alternative Exchange (ALT-X) of the Johannesburg Stock Exchange. Return on assets, revenue growth and headline earnings per share were used as financial performance indicators; while market-to-book ratio and total share return were used to measure market performance. Multivariate regressions were performed, with panel data covering 390 companies in the financial, basic materials, consumer services, consumer goods, industrial and technology industries from 2001 to 2011.

First, human capital efficiency was found to have no effect on the market performance of listed companies in South Africa. Secondly, higher human capital efficiency was found to result in the extraction of greater returns from both tangible and intangible assets in all industries. Thirdly, higher profitability was found to be associated with higher human capital efficiency in almost every industry in South Africa, with the exception of the technology industry, where human capital efficiency was found to be independent of headline earnings per share. Finally, higher revenue growth was found to be positively associated with human capital efficiency in those industries which are not consumer-driven. In the consumer-driven industries, human capital efficiency contributes to bottom line profitability even though it is not a driver for revenue growth.

Overall, the results of this study confirm that human capital efficiency enhances a company's financial performance, whether it be through a greater capacity for production and service delivery, tighter cost controls or better use of company resources. Management in all South African industries are encouraged to develop the value-creating abilities of their employees through employer-driven personnel enrichment and training programs and by incentivising workers to pursue further education.
\end{abstract}

Key words: human capital efficiency, human capital, value-added human capital, VAHU, value-added, competitive advantage, South Africa

JEL: J240, L250, M500

\section{$1 \quad$ Introduction}

In an industrialised economic environment, such as that in South Africa, the effective use of physical resources is considered to carry more weight than that of human and other intellectual resources in the production of goods and services (Firer \& Williams, 2003:357). Consequently, companies may take less care in the development and management of their human capital assets than they do in managing the efficiency and productivity of their tangible assets. However, human capital is the essence of innovation and is therefore crucial to the development of commercial products and the improvement of business processes (Stewart, 1998:76; Sullivan, 2000:9). The validity of this assertion may, however, differ from industry to industry.

According to the World Economic Forum, South Africa's Global Competitiveness Index world ranking has fallen from $36^{\text {th }}$ to $53^{\text {th }}$ since 2006 (The Global Competitiveness Report 2007-2008, 2007:10; The Global Competitiveness Report 2013-2014, 2013:15). The corresponding drop in South Africa's ranking in both Higher Education and Training, and Labour Market Efficiency implies a connection between these factors. To be truly competitive in the long run, whether locally or in the global arena, it is clear that South African businesses will be forced to cultivate their knowledge-based intangible assets, starting with their human capital. 
Creating opportunities for their employees to complete secondary or tertiary education or to attend in-house training courses is one way in which businesses in emerging economies can achieve this commercial imperative, and in so doing, indirectly serve the country's need for socioeconomic growth. However, the prevailing corporate culture is one in which human capital development expenditure is regarded as an opportunity cost. The aforementioned trade-off in South Africa between tangible and intellectual assets (Firer \& Stainbank, 2003:36) means that firms would rather spend available funds on the acquisition or development of property, plant and machinery for production. If employee education and skills development received more attention from the South African private sector and government, the outcome would be a workforce better equipped to bolster the country's economic growth in this age of global competition. This argument is supported by Judson (2002:229), who analysed data on educational spending, enrolment and educational attainment to confirm a positive relationship between economic growth and human capital accumulation.

Human capital and its development are difficult to quantify. In this study, human capital is measured by the efficiency with which it creates value for a business (hereafter known as "human capital efficiency"). The metric for human capital efficiency that has been used in this study, Value-Added Human Capital (VAHU), is best described as the value-added per unit of employeerelated input cost (Pulic, 2000:706). Human capital efficiency should not be confused with production efficiency, which refers to an employee's ability to deliver maximum output of the highest quality, using the least inputs, as fast as possible. Production efficiency is related to physical productivity, while the subject matter of this research - human capital efficiency - is related to value creation.

It is hoped that this study will spark a change in the collective perception of education, training and skills development as grudge expenses, rather than essential investments for corporate performance. Empirical research is needed to reinforce the notion that human capital efficiency is important to the success of South African commerce, and consequently the local economy. The primary objective of this research is therefore to investigate the relationship between human capital efficiency and the financial and market performance of South African companies across all industries.

The remainder of the article is organised as follows: the second section summarises prior local and international research relevant to the topic. The underlying conceptual framework is developed and the research methodology presented in the third section. The empirical results are presented and discussed in the penultimate sections, while the final section comprises conclusions reached and suggestions for further research.

\section{Literature review}

Ioannidis (2005:0696) argued that the strength of a research finding is based on the statistical power of the study, the expected probability of that outcome, the extent of replication, and the consistency of the conclusions reached across similar research. Most of the existing empirical studies about the impact of human capital on corporate performance were performed using Pulic's (2000:706) VAHU as the proxy for human capital. In addition, most studies examined emerging markets that were similar to the South African market. Based on Ioannidis' (2005:0696) criteria, the body of prior research on human capital and firm performance is limited in volume and scope and offers inconsistent, mixed results.

This study intends to further the pioneering exploratory research by Firer and Williams (2003:348), who examined the relationship between intellectual capital and corporate performance in South Africa. Due to the exploratory nature of their research, their sample was restricted to single-period data (2001) for 75 companies in only those industry sectors considered to have inherently high intellectual capital intensity - banking, electronic, information technology and services. Firer and Williams (2003:357) concluded that human capital efficiency is negatively associated with corporate productivity (as measured by asset turnover). This result supported Firer 
and Stainbank's (2003:36) finding of a trade-off between intellectual capital and tangible assets in South Africa. In order to enhance their productivity, firms were inclined to incur costs in improving the efficiency of their physical assets rather than that of their human capital resources. Although Firer and Williams (2003:357) found that market values declined when companies focused on better use of human capital instead of physical assets, no relationship could be established between VAHU and profitability.

Using the Ohlson (1995) value relevance model, Swartz, Swartz and Firer (2006:78) empirically confirmed that human capital efficiency (measured by VAHU) has a significant and robust positive effect on share prices on the Johannesburg Stock Exchange (JSE). Although the Ohlson (1995) model was deemed unsuitable for this study due to the extent of risk estimations required, their use of share prices three months after each company's financial year-end was adopted. JSE-listed companies are granted three months after year-end to disseminate either their unaudited provisional financial statements or the audited financial statements (JSE Limited Listing Requirements - Service Issue 13, 2010:3-7). This timing difference between the financial and share data is needed to allow the impact of investor and market reactions to the financial statements to reflect in the share prices.

Firer and Williams (2003) and Swartz et al. (2006) examined only the JSE Main Board. The JSE Alternative Exchange (ALT-X) raises development funding for high growth, small market capitalisation companies to encourage entrepreneurship and black economic empowerment. Research encompassing both the Main Board and ALT-X may be considered a better reflection of the true South African market.

The studies by Firer and Williams (2003) and Swartz et al. (2006) deliver contradictory results, leaving no clear consensus on the impact in South Africa of human capital efficiency on the various measures of firm performance. Unfortunately, the research results of international studies do not provide much clarification.

Chen, Cheng and Hwang (2005:159) found a weak positive link between human capital efficiency and the financial and market performance of companies listed on the Taiwan Stock Exchange from 1992 to 2002. Taiwanese firms that display higher human capital efficiency perform only slightly better in terms of market valuation and profitability, as measured by marketto-book ratio, return on equity, return on assets, revenue growth and employee productivity. Shiu (2006:363) examined the technology sector in Taiwan and his conclusions contradicted those of Chen et al. (2005:159). Shiu found no relationship between human capital efficiency and return on assets or market-to-book ratio, yet found VAHU to have a positive impact on asset turnover. Shiu may be criticised for restricting all negative company VAHU to zero in order to derive "meaningful" correlation (Shiu, 2006:359). Negative VAHU data should be used as is and should not be transformed - correlation analysis describes the direction and strength of the linear association between two variables, without imposing requirements on the sign or amount of each variable.

Gan and Saleh (2008:113) found that, in Malaysia, the value-creating efficiency of a firm's human capital resource base is a direct determinant of its profitability and productivity (as measured by return on assets and asset turnover respectively). They found that human capital efficiency had no effect on market-to-book ratio, and suggested that share prices in a young, emerging market such as Malaysia may be driven more by fundamental theory than a more mature stock market would be (Gan \& Saleh, 2008:127). They warned that the results may not be representative of the entire Malaysian market because their data was restricted to technologyintensive companies listed on the MESDAQ, a sub-division of the Bursa Malaysia Berhad similar to the JSE ALT-X (Gan \& Saleh, 2008:127).

An empirical study of four sectors of the Athens Stock Exchange by Maditinos, Chatzoudes, Tsairidis and Theriou (2011:146) confirmed that human capital development is a necessary factor for corporate success as it is a determinant in share pricing. They confirmed a positive relationship between VAHU and return on equity, but could not establish any between human capital and revenue growth or return on assets. Puntillo (2009:112) concluded that human capital efficiency 
does not influence return on assets or market-to-book ratio in the Italian financial sector. However, the degree of approximation and extrapolation in her calculation of VAHU poses a strong argument for using staff costs as disclosed in audited financial statements.

Appuhami (2007:24) confirmed a strong positive relationship between VAHU and investor capital gains in the Thai financial sector in 2005. Muhammad and Ismail (2009:210) investigated the impact of human capital efficiency on financial and market performance in the Malaysian financial sector, but regarded their regression results as inconclusive due to their small sample size and coverage of a single year (2007). They could not establish any significant relationship between VAHU and company performance (Muhammad \& Ismail, 2009:210). Using a different research sample - the top 25 drug and pharmaceutical companies on the Bangladesh Stock Exchange from 1996 to 2006 - Kamath (2008:700) reached similar conclusions. He confirmed that corporate performance is independent of human capital efficiency.

Several shortcomings were identified in the review of prior literature. Although single-period data was used in most of the prior research, analyses covering a longer time period may yield more meaningful results (Firer \& Stainbank, 2003:41; Firer \& Williams, 2003:358; Maditinos et al., 2011:146; Tseng \& Goo, 2005:199). There is a greater risk of "sampling within a sample" if research is limited to heavily intellectual capital-based sectors only (Firer \& Williams, 2003:358; Maditinos et al., 2011:146). By addressing these limitations through cross-sectional, time-series analysis incorporating all industries of the JSE Main Board and ALT-X, it is hoped that this study will add value to the existing body of human capital research in South Africa.

\section{Methodology}

\subsection{Developing the regression models}

The research population of this study consisted of all 390 companies listed on the Main Board and ALT-X of the JSE for the financial years falling in the period 31 December 2001 to 30 June 2011, resulting in 1765 company years' of empirical data. Time-series cross-sectional multivariate regressions were used to analyse the impact of human capital on various financial and market performance measures in different South African industries over the period under review. H1-a to H1-e were each performed for six industries - Financials, Basic Materials, Consumer Services, Consumer Goods, Industrials and Technology - resulting in a total of thirty regressions.

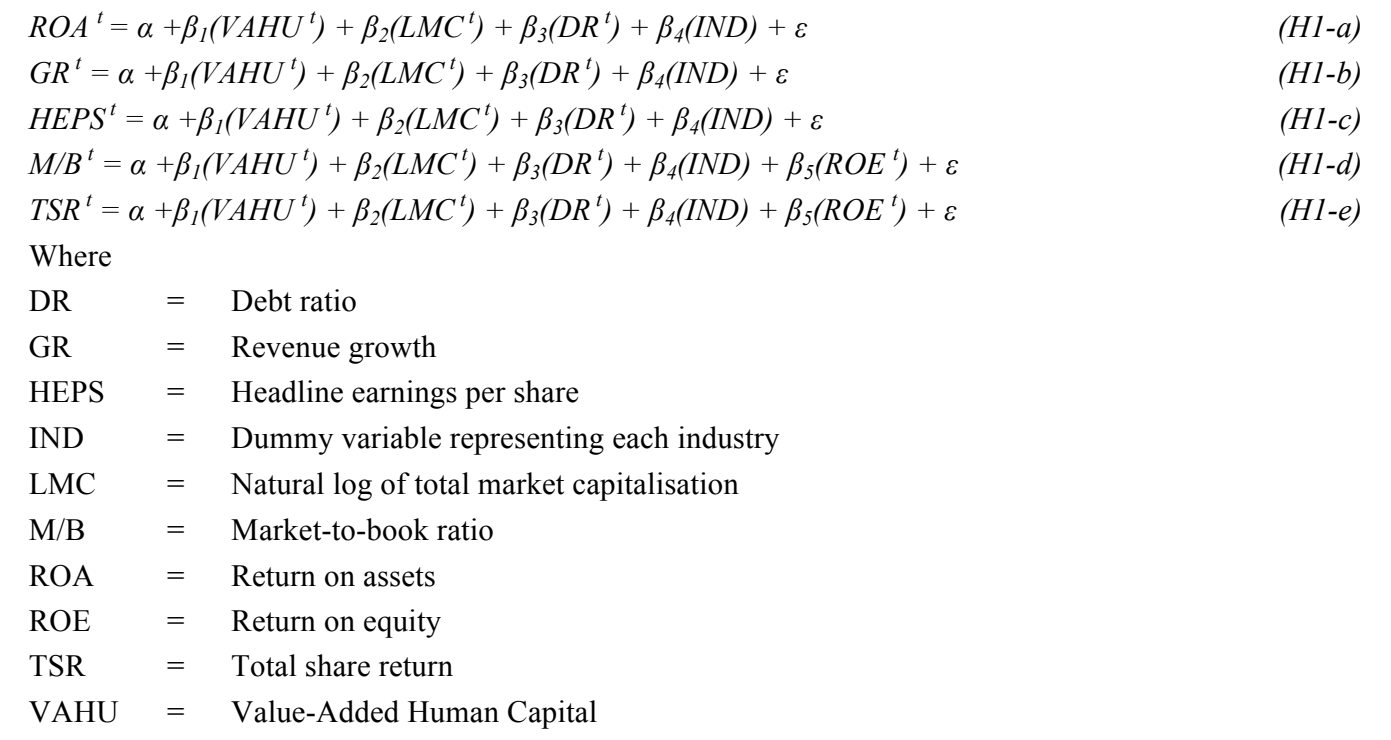


The use of panel data decreases regression errors in samples where significant time-series depth is lacking (De Jager, 2008:56). All empirical data - audited annual financial statements, monthly share data and market indicators - was obtained from the McGregor Bureau of Financial Analysis database. Survivorship bias was avoided by explicitly including all companies listed on the JSE at any time during the research period, regardless of whether they had subsequently delisted or remained listed.

\subsection{Measuring human capital efficiency}

Pulic's (2000:707) measure of human capital efficiency, VAHU, was used as the measure of the independent variable in this study. He calculated VAHU as value-added per unit cost of salaries and wages. Refining Pulic's concept, Riahi-Belkaoui (2003:220) and Chen et al. (2005:166) proposed that value-added be calculated as net profit before interest, taxes and salaries and wages. Therefore, the independent variable was calculated as:

$$
\mathrm{VAHU}=\frac{\mathrm{NP}+\mathrm{I}+\mathrm{T}+\mathrm{W}}{\mathrm{W}}
$$

$$
\begin{aligned}
\text { where } & \\
\mathrm{NP} & =\text { net profit after tax } \\
\mathrm{I} & =\text { interest expense } \\
\mathrm{T} & =\text { total of all taxes } \\
\mathrm{W} & =\text { salaries and wages }
\end{aligned}
$$

Directors' emoluments are often much higher, more subjective and determined in a less marketrelated manner than those of management and other employees. To avoid distortion of the intended meaning of the VAHU variable, directors' remuneration has been excluded from its calculation This exclusion is further supported by Pantzalis and Park's (2009:1610) assertion that the compensation received by employees reflects the value of human capital to the labour market, as it is a market pricing effect of the need to attract employees amidst labour market competition.

JSE-listed companies are required to have their financial statements audited by independent, external auditors and to make them available to their shareholders periodically. VAHU therefore offers a uniform, standardised calculation based on reliable and readily available financial statement information, which is both simple to replicate and allows for ease of comparison between companies. Firer and Stainbank (2003:32), Firer and Williams (2003:353) and Swartz et al. (2006:74) provided similar motivation for their use of Pulic's human capital metric. VAHU is also very similar to the metric for wealth creation efficiency, $\mathrm{P}_{2}$, in the annual Value-Added Scoreboard report of the United Kingdom Department for Business Innovation and Skills (United Kingdom, 2009:55).

The selection of company size (LMC) and financial leverage (DR) as control factors is supported by Kamath (2008:692), Riahi-Belkaoui (2003:221), Shiu (2006:360), Firer and Stainbank (2003:32) and Firer and Williams (2003:354). ROE was included as an additional control factor in H1-d and H1-e to encapsulate the effect of a company's financial performance on its market performance. It is calculated by dividing earnings before interest, tax, depreciation and amortisation by the average book value of equity.

\subsection{Measuring corporate financial and market performance}

ROA, GR and published HEPS were considered to be appropriate proxies for financial performance:

$$
\begin{aligned}
& \mathrm{ROA}=\frac{\text { Earnings before interest, tax, depreciation and amortisation }}{\text { Average total assets }} \\
& \mathrm{GR}=\frac{\text { Current year revenue }}{\text { Prior year revenue }}-1
\end{aligned}
$$


ROA is a measure of the efficiency, effectiveness and economy with which a company utilises its assets to generate profits, while GR is indicative of its potential for future growth. HEPS is a sophisticated earnings per share figure (SAICA Circular 08/07 Headline earnings, 2010:4), which is mandatorily disclosed by all JSE-listed companies (JSE Limited Listing Requirements - Service Issue 13, 2010:8-20), and is commonly used in South African analyst reports to assess company performance.

$\mathrm{M} / \mathrm{B}$ and TSR were chosen to represent market performance:

$\mathrm{M} / \mathrm{B}=$ Ordinary share price $x$ Number of shares in issue

Book value of total assets - Book value of total liabilities

$\mathrm{TSR}=$

(End share price - Start share price) + Annual dividend per share Start share price

$\mathrm{M} / \mathrm{B}$ reflects stock market performance because the higher the $\mathrm{M} / \mathrm{B}$, the better the company's ability to influence its stock market value through the management of its net assets. TSR represents the total return gained by an ordinary shareholder as it incorporates both the capital gain and the dividend declared per share (Tan, Plowman \& Hancock, 2007:82).

\subsection{Tests of statistical integrity}

Various data transformations were performed to ensure the statistical reliability of the regressions, with minimal adjustment to the underlying data. Share volumes in the research data were adjusted for share splits and consolidations, to ensure consistency over the research time period. Although the control factors and ROA were found to be normally distributed, VAHU and the remaining dependent variables were positively skewed and displayed leptokurtosis (refer to Table 1). This non-normality is considered acceptable, as it is common in financial ratios (Barnes, 1982:51; Deakin, 1976:95; So, 1987:488) since positive skewness would prevail in ratios with a lower limit of zero and no real upper limit (Ezzamel, Mar-Molinero \& Beecher, 1987:466). Outlier bias was addressed conservatively by winsorising only the outlier portion of extreme values to three standard deviations from the population mean - a technique preferable to other marginal models (Tsay, Pena \& Pankratz, 2000:803). Heteroskedasticity was rectified through robust covariance matrix estimation (Hayes \& Cai, 2007:714).

\section{Results}

\subsection{Descriptive statistics and correlation analysis}

The descriptive statistics of the research population are presented in Table 1. While the median ROA was fairly high at $17.5 \%$, the median VAHU clearly indicates that South African companies on the JSE were able to generate value from their human capital. The financial health of South African listed companies over the period under review appears to be strong, as the median TSR of $16.8 \%$ is much higher than the prime rate of interest in South Africa (which declined from 13\% to $9 \%$ over the period) and the median GR of $12.9 \%$ is considerably higher than the target inflation rate of $3 \%$ to $6 \%$ over the period under review. Those favourable conditions translated into higher share valuations, attested by a median $\mathrm{M} / \mathrm{B}$ greater than 1 , despite the usual concerns surrounding emerging markets, such as weaker information environments, questionable corporate governance, lack of transparency and liquidity, and governmental corruption (Bruner, Conroy, Estrada, Kritzman \& Li, 2002:319). 
Table 1

Descriptive statistics of the research population

\begin{tabular}{|l|r|r|r|r|r|r|}
\hline & Median & Min & Max & \multicolumn{1}{c|}{$\begin{array}{l}\text { Standard } \\
\text { deviation }\end{array}$} & Skewness & Kurtosis \\
\hline Human capital efficiency & 1.724 & -0.325 & 4.434 & 1.190 & 8.605 & 278.276 \\
\hline Return on assets & 0.175 & -0.483 & 0.959 & 0.139 & 0.261 & 3.526 \\
\hline Revenue growth & 0.129 & -0.306 & 0.601 & 0.227 & 28.704 & 995.441 \\
\hline Headline earnings per share & 71.300 & -250.786 & 570.392 & 205.295 & 37.826 & 1518.415 \\
\hline Market-to-book ratio & 1.441 & 0.000 & 5.135 & 1.589 & 25.300 & 763.863 \\
\hline Total share return & 0.168 & -0.772 & 1.191 & 0.491 & 13.132 & 262.531 \\
\hline Company size & 14.076 & 4.564 & 20.285 & 2.438 & -0.132 & -0.144 \\
\hline Financial leverage & 0.407 & 0.000 & 0.978 & 0.253 & 0.160 & -0.933 \\
\hline Return on equity & 0.299 & -1.152 & 3.440 & 0.340 & 2.108 & 12.276 \\
\hline
\end{tabular}

Table 2 presents the bivariate pairwise correlation analyses performed to establish a linear relationship between the independent, dependent and control variables prior to undertaking the regressions. No excessively strong correlations ( 0.7 and higher or -0.7 and lower) were found between any of the variables. VAHU was found to have a positive and statistically significant linear relationship with all measures of financial and market performance. This supports the traditional thinking that human capital efficiency has a positive effect on corporate performance. VAHU was more strongly associated with ROA and HEPS than the other dependent variables. GR showed a moderate association with VAHU, while the relationships between VAHU and both $\mathrm{M} / \mathrm{B}$ and TSR were weak.

Table 2

Correlation matrix for the regression variables

\begin{tabular}{|c|c|c|c|c|c|c|c|c|c|}
\hline & VAHU & ROA & GR & HEPS & $M / B$ & TSR & LMC & DR & ROE \\
\hline VAHU & 1.000 & & & & & & & & \\
\hline ROA & 0.489 & 1.000 & & & & & & & \\
\hline GR & 0.193 & 0.223 & 1.000 & & & & & & \\
\hline HEPS & 0.328 & 0.313 & 0.081 & 1.000 & & & & & \\
\hline$M / B$ & 0.104 & 0.156 & 0.088 & 0.097 & 1.000 & & & & \\
\hline TSR & 0.141 & 0.273 & 0.110 & 0.156 & 0.136 & 1.000 & & & \\
\hline LMC & 0.321 & 0.159 & 0.052 & 0.528 & 0.490 & 0.099 & 1.000 & & \\
\hline DR & 0.128 & -0.150 & $0.044^{*}$ & 0.075 & 0.304 & -0.139 & 0.196 & 1.000 & \\
\hline ROE & 0.445 & 0.644 & 0.187 & 0.283 & 0.300 & 0.131 & 0.224 & 0.381 & 1.000 \\
\hline
\end{tabular}

\subsection{Industry VAHU}

Traditional thinking would imply that the value-generating ability of human capital would be expected to be higher in those industries where the quality, expertise, training and skill of the employee base are perceived as better. Therefore, the average VAHU would be expected to be higher in Financials, Technology and perhaps Consumer Services. Conversely, the average VAHU in Industrials, Consumer Goods and Basic Materials would intuitively be expected to be lower. Although the median VAHU of each industry (presented in Table 3) roughly resembles this instinctive industry ranking, human capital efficiency was found to be higher than expected in Basic Materials and lower than expected in Technology.

The high human capital efficiency of workers in Basic Materials may be attributable to the mining situation in South Africa, where heavily under-paid, unskilled labourers produce mineral outputs that are worth countless times more than the Rand cost of their wages. Industrial action in response to this inequity has resulted in the loss of more working hours in this industry than in any other (Republic of South Africa, 2011:17). 
Table 3

Human capital efficiency per industry

\begin{tabular}{|l|c|}
\hline & Median \\
\hline Financials & 3.247 \\
\hline Basic materials & 2.042 \\
\hline Consumer services & 1.709 \\
\hline Consumer goods & 1.695 \\
\hline Industrials & 1.524 \\
\hline Technology & 1.425 \\
\hline
\end{tabular}

Workers in the field of computer services, telecommunications and information technology are presumed to hold specialised knowledge and expertise. Yet this knowledge capital does not guarantee that value will be added, as many working hours may be spent on research and development or experimental projects which are not profitable later. The lower than expected VAHU in Technology is therefore likely to be attributable to the nature of the industry, in that certain human capital expenditure might not result in earnings.

\subsection{Regression results}

Given the large number of regressions performed, the regression results are presented diagrammatically in industry panels in Figure 1. For ease of reading, the regression outputs were limited to the $\beta$ coefficients for VAHU - i.e. those which directly describe the impact of human capital efficiency on the dependent variables.

Figure 1

Regression of corporate performance on human capital efficiency

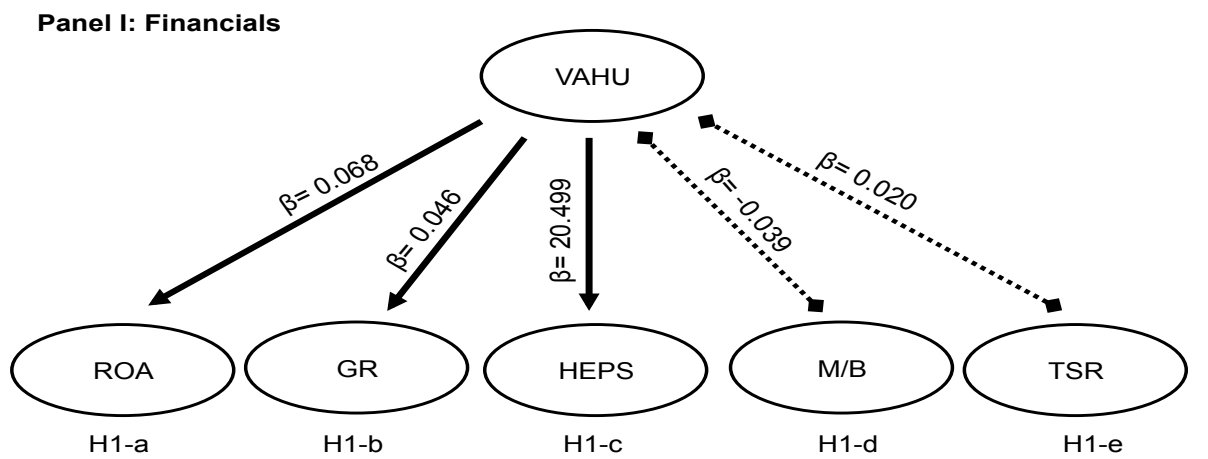

Panel II: Basic materials

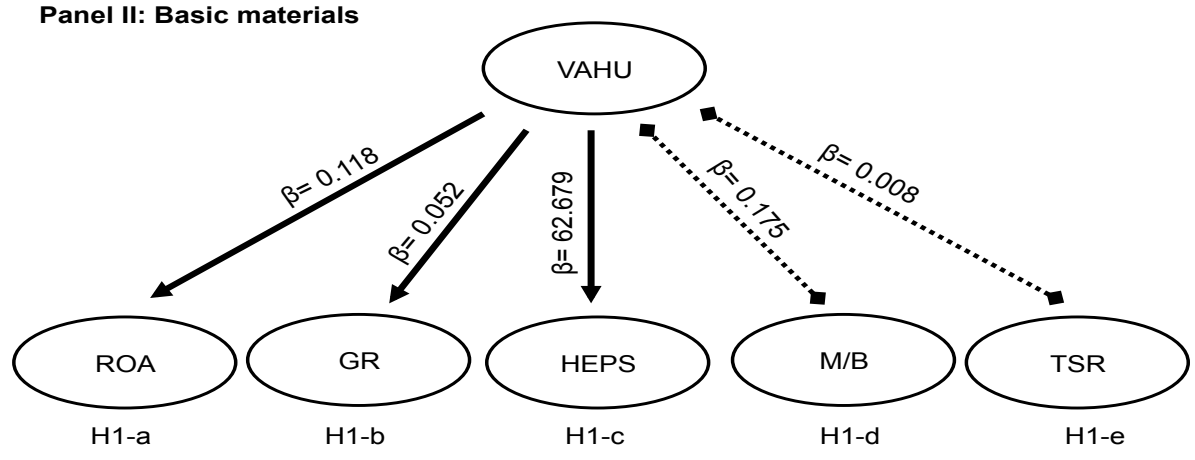



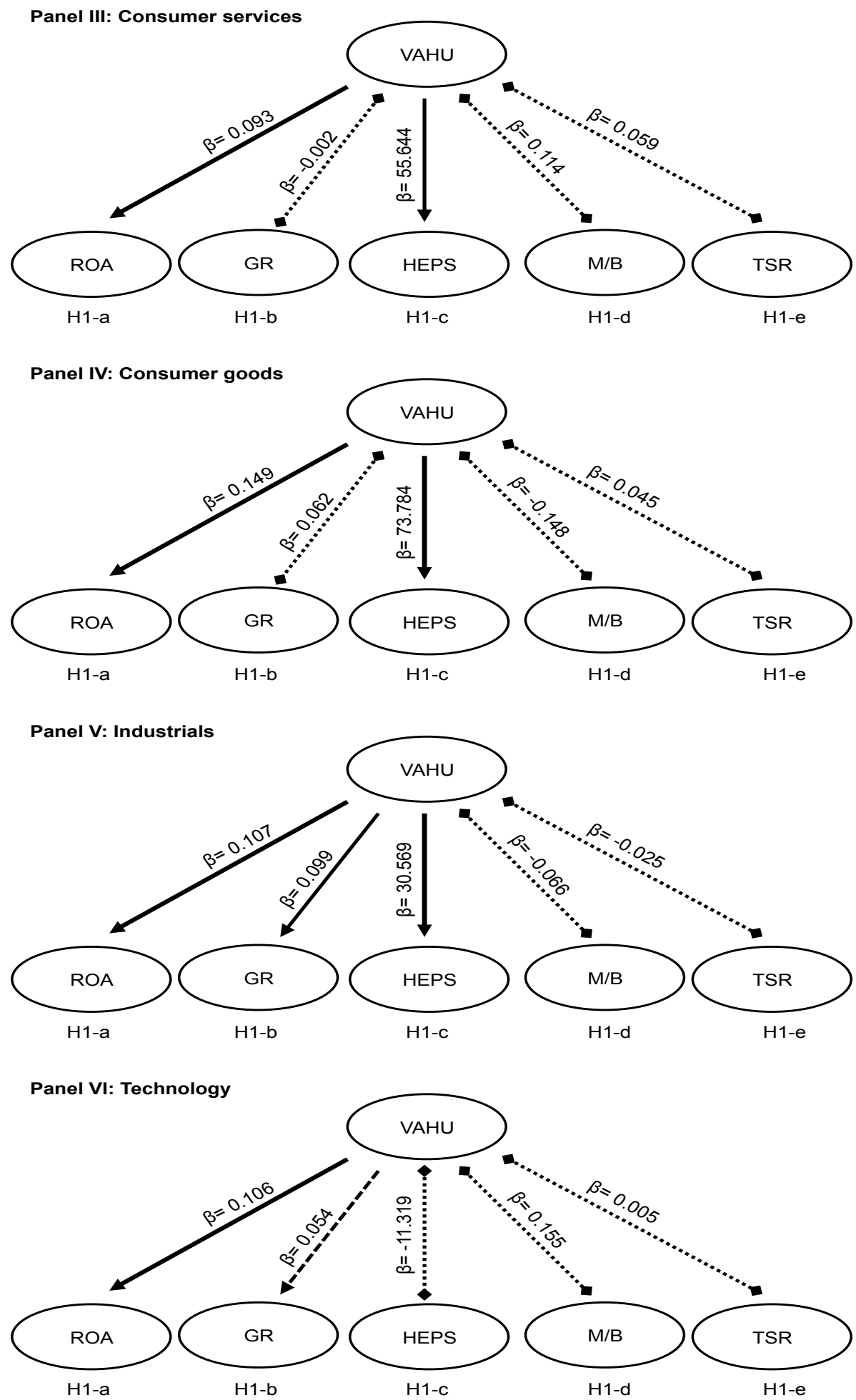
A very high VAHU $\beta$ was observed with respect to HEPS in all industries (H1-c in Panel I to VI of Figure 1). These coefficients were all statistically significant $(p<0.05)$, with the exception of Technology. The magnitude of these standardised coefficients is a strong indication of multicollinearity. Therefore the $\beta$ coefficients may still be used to describe the direction of the relationship between VAHU and HEPS, but they grossly overstate the strength of that relationship.

\section{Intra-industry analysis}

The coefficient for VAHU was positive and statistically significant $(p<0.05)$ with respect to ROA, GR and HEPS for Basic Materials, Financials and Industrials. The VAHU $\beta$ coefficient was statistically significant $(p<0.05)$ and positive with respect to ROA and HEPS in Consumer Goods and Consumer Services. However, their VAHU coefficients relating to GR were not statistically significant. The VAHU coefficients relating to HEPS were not statistically significant in Technology, but the $\beta$ coefficients relating to ROA $(p<0.01)$ and GR $(p<0.10)$ were significantly positive.

The $\beta$ coefficient was not statistically significant with respect to M/B and TSR in any industry.

\section{Inter-industry analysis}

The regression results for each measure of financial and market performance were analysed across the different industries in order to identify any trends. The VAHU $\beta$ relating to GR was statistically significant $(p<0.10)$ and positive in Basic Materials, Financials and Industrials; although it was not significant in Consumer Goods and Consumer Services. VAHU was found to have a significantly positive $\beta(p<0.05)$ for HEPS in all industries, except Technology (where it was not significant). The $\beta$ coefficient for VAHU was found to be positive and statistically very highly significant $(p<0.001)$ with respect to ROA in all the industries. ROA also displayed the strongest association with VAHU in the preliminary correlation analysis (refer to Table 2 ). On the other hand, no significant $\beta$ coefficients were identified for VAHU with respect to $\mathrm{M} / \mathrm{B}$ and TSR in any industry.

\section{Discussion}

The conclusions formulated from the individual industry regressions have been summarised in Table 4. Much of the prior research on this subject matter was inconsistent or inconclusive, at best. The outcomes of this study, however, paint a far more definitive picture of the relationship between human capital efficiency and firm performance across the various industries in South Africa.

Table 4

Summary of the effect of human capital efficiency on corporate performance

\begin{tabular}{|l|c|c|c|c|c|c|}
\hline & H1-a & H1-b & H1-c & H1-d & H1-e \\
\hline & $\begin{array}{c}\text { Return on } \\
\text { assets }\end{array}$ & $\begin{array}{c}\text { Revenue } \\
\text { growth }\end{array}$ & $\begin{array}{c}\text { Headline } \\
\text { earnings per } \\
\text { share }\end{array}$ & $\begin{array}{c}\text { Market-to-book } \\
\text { ratio }\end{array}$ & $\begin{array}{c}\text { Total share } \\
\text { return }\end{array}$ \\
\hline Financials & Positive & Positive & Positive & None & None \\
\hline Basic Materials & Positive & Positive & Positive & None & None \\
\hline Consumer Services & Positive & None & Positive & None & None \\
\hline Consumer Goods & Positive & None & Positive & None & None \\
\hline Industrials & Positive & Positive & Positive & None & None \\
\hline Technology & Positive & Positive & None & None & None \\
\hline
\end{tabular}

Human capital efficiency has little to no effect on a company's market performance in South Africa, irrespective of the industry in which it operates. Neither the premium to net asset value at which a company trades (i.e. $\mathrm{M} / \mathrm{B}$ ), nor capital and dividend returns (i.e. TSR), appear to be influenced by VAHU. This contradicts the positive impact of VAHU on share prices (Swartz et 
al., 2006:78) and negative impact on M/B (Firer \& Williams, 2003:357) observed in earlier exploratory South African studies. In addition, this result challenges prior research in Greece (Maditinos et al., 2011:146) and Italy (Puntillo, 2009:112) which confirmed a positive relationship between the variables.

As experienced in other emerging economies such as Malaysia (Gan \& Saleh, 2008:127) and Thailand (Appuhami, 2007:24), the independence of market performance from human capital efficiency may be due lack of sophistication in a relatively young stock exchange. In emerging stock markets, market sentiment is a stronger driver of share prices than fundamental analysis (Gan \& Saleh, 2008:127). It is therefore plausible that, in South Africa, public perceptions about corruption, crime and other prominent macroeconomic and microeconomic conditions play a bigger role in share pricing than human capital efficiency does.

Higher VAHU was found to be associated with higher ROA in all the industries in South Africa. This finding is in contrast with that by Firer and Williams (2003:356), who could not identify any meaningful relationship. Human capital enhancement directly influences operational performance in a manufacturing environment by improving staff productivity, machine efficiency and customer satisfaction (Youndt, Snell, James \& Lepak, 1996:858). In an industrialised economy where intellectual capital investment is overlooked in favour of investment in physical assets, propagating the trade-off between physical assets and human capital may result in poorer financial performance.

Consumer Goods and Consumer Services are composed of food and beverage retailers, the fishing and farming sectors, motor manufacturers, other retailers and personal services providers. Although service delivery and production in these industries remains dependent on human capital to some degree, the financial performance of the companies in these two industries is driven primarily by consumer demand. As could therefore be expected, VAHU was found to offer little to no explanatory power for GR in these industries despite having a favourable effect on the bottom line (through higher ROA and HEPS).

HEPS was found to be independent of VAHU in Technology. This is possibly due to the research and development side of the industry's operations, which is also considered to be the cause of the unexpectedly low value-generating ability of its workforce. Firer and Williams (2003:357) observed a similar disassociation between profitability and human capital efficiency in the information sector. VAHU was still found to positively impact all the other measures of financial performance in Technology and Industrials.

VAHU contributes positively to ROA, GR and HEPS in Financials and Basic Materials. Therefore, higher human capital efficiency results in a stronger financial performance in those industries where employees have a greater capacity for deriving company value from their knowledge and skills (i.e. those industries with higher VAHU) This clarifies prior research in the Malaysian financial sector (Muhammad \& Ismail, 2009:210) and in South Africa (Firer \& Williams, 2003:357), which found no clear association between VAHU and profitability.

\section{Conclusion}

The scope of this investigation into the relationship between human capital efficiency and corporate performance in South Africa was broad. Thirty multivariate regressions were performed, involving both inter-industry and intra-industry testing of the impact of VAHU on five measures of financial and market performance (ROA, GR, HEPS, M/B and TSR) across all six industries of the JSE over a ten-year period. These analyses consequently offer deeper insights than prior research, which were either exploratory, lacking in time depth or were largely restricted to economic sectors not inherently intensive in intellectual capital.

Firstly, human capital efficiency was found to have little to no direct effect on the market performance of listed companies in South Africa. This may be because investor perceptions carry more weight than fundamental analysis in share pricing in emerging markets (Gan \& Saleh, 2008:127). 
Secondly, higher human capital efficiency was found to result in the extraction of greater returns from both tangible and intangible assets in all the industries. Management are advised to build the value-creating competencies of their workforce through skills development and training of workers in order to derive greater benefit from the company's physical capital resources. A more competent employee would also be better able to draw value from the company's intangible assets - through innovation, improvements in organisational culture and exploiting stakeholder relationships for competitive advantage. This finding debunks the South African tendency to tradeoff intellectual capital expenditure in favour of investment in physical assets (Firer \& Stainbank, 2003:36).

Thirdly, higher profitability was found to be associated with higher human capital efficiency in almost every industry in South Africa. Employee remuneration is often the largest expense in any company's income statement. Because minimising this cost usually means a reduction in the size of the workforce that is accompanied by diminished production capacity, it does not guarantee higher headline earnings. Instead, South African companies should focus on improving the valuecreating ability of their employees through the provision of job-specific training and incentivising workers to pursue further education. The exception to this finding is in Technology, where human capital efficiency was found to be independent of profitability - further industry-specific investigation may shed light on this unusual phenomenon.

Finally, higher revenue growth was found to be positively associated with human capital efficiency in those industries which are not consumer-driven. The perceived degree of intensity in intellectual capital or knowledge capital of an industry does not appear to affect the relationship between human capital and revenues. In the non-consumer-driven industries - Financials, Basic Materials, Industrials and Technology industries - optimising the value-added per Rand of employee costs is associated with stronger growth in business revenues. In the consumer-driven industries (Consumer Services and Consumer Goods), however, it was established that human capital efficiency is not a driver for revenue growth. In such industries, the microeconomics of supply and demand is the chief driving force behind a company's turnover. As with all the other industries, management in consumer-driven industries are nevertheless encouraged to develop the value-generating abilities of their workers through employee enrichment and training programs. Overall, the results of this study indicate that human capital efficiency enhances a company's financial performance - be it through a greater capacity for production and service delivery, tighter cost controls or better use of company resources.

As discussed, the measure of human capital efficiency used in this research does not incorporate the cost of employer-funded employee skills development and excludes the remuneration of directors. Incorporating the value-creating efficiency of directors may yield different results. Alternatively, isolating it may lend support for or against the common practice of paying directors a substantially higher level of remuneration. Finally, provided that empirical training cost data could be collected, a separate investigation into the value-added per Rand spent on employee training might cultivate a stronger corporate commitment to staff enrichment and empowerment.

\section{References}

APPUHAMI, B.A.R. 2007. The impact of intellectual capital on investors' capital gains on shares: An empirical investigation of Thai banking, finance and insurance sector. International Management Review, $3(2): 14-25$.

BARNES, P. 1982. Methodological implications of non-normally distributed financial ratios. Journal of Business Finance \& Accounting, 9(1):51-62.

BRUNER, R.F., CONROY, R.M., ESTRADA, J. KRITZMAN, M. \& LI, W. 2002. Introduction to 'Valuation in emerging markets'. Emerging Markets Review, 3:310-324.

CHEN, M.-C., CHENG, S.-J. \& HWANG, Y. 2005. An empirical investigation of the relationship between intellectual capital and firms' market value and financial performance. Journal of Intellectual Capital, 6(2):159-176. 
DE JAGER, P. 2008. Panel data techniques and accounting research. Meditari Accountancy Research, 16(2):53-68.

DEAKIN, E.B. 1976. Distributions of financial accounting ratios: Some empirical evidence. The Accounting Review, 51(1):90-96.

EZZAMEL, M., MAR-MOLINERO, C. \& BEECHER, A. 1987. On the distributional properties of financial ratios. Journal of Business Finance \& Accounting, 14(4):463-481.

FIRER, S. \& STAINBANK, L. 2003. Testing the relationship between intellectual capital and a company's performance: Evidence from South Africa. Meditari Accountancy Research, 11:25-44.

FIRER, S. \& WILLIAMS, S.M. 2003. Intellectual capital and traditional measures of corporate performance. Journal of Intellectual Capital, 4(3):348-360.

GAN, K. \& SALEH, Z. 2008. Intellectual capital and corporate performance of technology-intensive companies: Malaysia evidence. Asian Journal of Business and Accounting, 1(1):113-130.

HAYES, A.F. \& CAI, L. 2007. Using heteroskedasticity-consistent standard error estimators in OLS regression: An introduction and software implementation. Behaviour Research Methods, 39(4):709-722. IOANNIDIS, J.P.A. 2005. Why most published research findings are false. PLoS Medicine, 2(8):0696-0701. Available at: http://www.plosmedicine.org/article/info \%3 Adoi\%2F10.1371\%2Fjournal.pmed.0020124 [accessed 2012-04-16].

JSE LIMITED LISTING REQUIREMENTS - SERVICE ISSUE 13. 2010. Available at: http://www.jse.co.za/ How-To-List-A-Company/Main-Board/Listing-requirements/JSE-listing-requirements.aspx [accessed 201106-24].

JUDSON. R. 2002. Measuring human capital like physical capital: What does it tell us? Bulletin of Economic Research, 54(3):209-231.

KAMATH, G.B. 2008. Intellectual capital and corporate performance in Indian pharmaceutical industry. Journal of Intellectual Capital, 9(4):684-704.

MADITINOS, D., CHATZOUDES, D., TSAIRIDIS, C. \& THERIOU, G. 2011. The impact of intellectual capital on firms' market value and financial performance. Journal of Intellectual Capital, 12(1):132-151.

MUHAMMAD, N.M.N \& ISMAIL, M.K.A. 2009. Intellectual capital efficiency and firms' performance: Study on Malaysian financial sectors. International Journal of Economics, 1(2):206-212.

PANTZALIS, C. \& PARK, J.C. 2009. Equity market valuation of human capital and stock returns. Journal of Banking and Finance, 33:1610-1623.

PULIC, A. 2000. VAIC ${ }^{\mathrm{TM}}$ - an accounting tool for IC management. International Journal of Technology Management, 20(5-8):702-714.

PUNTILLO, P. 2009. Intellectual capital and business performance - Evidence from Italian banking industry. Electronic Journal of Corporate Finance, 4(12):97-115. Available at: http://cfjournal.hse.ru/data/2010/12/31/ 1208181600/Puntillo_96_115.pdf [accessed 2012-04-10].

REPUBLIC OF SOUTH AFRICA. Department of Labour. 2011. Annual Industrial Action Report 2011 Available at: http://www.labour.gov.za/documents/ annual-reports/ industrial-action-annualreport/2011/industrial-action-report-2011 [accessed 2013-06-19].

RIAHI-BELKAOUI, A. 2003. Intellectual capital and firm performance of US multinational firms: A study of the resource-based and stakeholder views. Journal of Intellectual Capital, 4(2):215-226.

SAICA CIRCULAR 08/07 HEADLINE EARNINGS. 2010. SAICA Handbook 2010/2011 Volume 3. Pietermaritzburg: SAICA. 1-22.

SHIU, H. 2006. The application of the value added intellectual coefficient to measure corporate performance: Evidence from technological firms. International Journal of Management, 23(2):356-365.

SO, J.C. 1987. Some empirical evidence on the outliers and the non-normal distribution of ratios. Journal of Business Finance \& Accounting, 14(4):483-496.

STEWART, T.A. 1998. Intellectual capital: The new wealth of organizations. London: Brealey.

SULLIVAN, P.H. 2000. Value-driven intellectual capital: How to convert intangible corporate assets into market value. New York: Wiley.

SWARTZ, G.E., SWARTZ, N.-P. \& FIRER, S. 2006. An empirical examination of the value relevance of intellectual capital using the Ohlson (1995) valuation model. Meditari Accountancy Research, 14(2):67-81. 
TAN, H.P., PLOWMAN, D. \& HANCOCK, P. 2007. Intellectual capital and financial returns of companies. Journal of Intellectual Capital, 8(1):76-95.

THE GLOBAL COMPETITIVENESS REPORT 2007-2008. 2007. World Economic Forum. Available at: https://members.weforum.org/pdf/Global_Competitive ness_Reports/Reports/gcr_2007/gcr2007_rankings.pdf [accessed 2011-06-30].

THE GLOBAL COMPETITIVENESS REPORT 2013-2014. 2013. World Economic Forum. Available at: http://www3.weforum.org/docs/WEF_GlobalCompetitive nessReport_2013-14.pdf [accessed 2014-07-02]. TSAY, R.S., PENA, D. \& PANKRATZ, A.E. 2000. Outliers in multivariate time series. Biometrika, 87(4):789-804.

TSENG, C. \& GOO, Y. J. 2005. Intellectual capital and corporate value in an emerging economy: Empirical studies of Taiwanese manufacturers. $R \& D$ Management, 35(2):187-201.

UNITED KINGDOM. Department for Business Innovation and Skills. 2009. The 2009 value added scoreboard: The top $800 \mathrm{UK}$ and 750 European companies by value added - Commentary and analysis. Available: http://webarchive.nationalarchives.gov.uk/20100908131539/http://innovation.gov.uk/ value_added/downloads/2009_ValueAdded_Analysis.pdf [accessed 2011-08-26].

YOUNDT, M.A., SNELL, S.A., JAMES, W.D. Jr. \& LEPAK, D.P. 1996. Human resource management, manufacturing strategy, and firm performance. The Academy of Management Journal, 39(4):836-866. 